\title{
PEMBERIAN KOMPRES HANGAT TERHADAP PEMULIHAN FUNGSI PERISTALTIK USUS PADA PASIEN POST OPERASI SECTIO CAESARIA DENGAN ANASTESI SAB (Di Kamar Bersalin RSUD Nganjuk)
}

\author{
Handoko Susilo ${ }^{1}$, Henny Purwandari ${ }^{2}$, H.M. Suhudi ${ }^{3}$ \\ ${ }^{12}$ STIKes Satria Bhakti Nganjuk, ${ }^{3}$ RSUD Nganjuk \\ Email : handokosusilo7@gmail.com
}

\begin{abstract}
Introduction : Caesarian Sectio Surgery there are two types of anesthesia namely Sub Arachnoid Block (SAB) and General Anesthesia, but the type of SAB anesthesia is considered safer for the mother and fetus. The effect of SAB is a decrease in intestinal peristaltic. Warm compresses as nonpharmacological means are considered capable of increasing intestinal peristalsis. The purpose of this study was to determine the effect of warm compresses on the recovery of intestinal peristaltic function in postoperative sectio caesaria patients with SAB anesthesia in the Maternity Room Nganjuk Hospital. Methods : The research design was pre-experiment with one group pretest-posttest design approach. The study was conducted on 1 - 30 April 2018 in the Maternity Room of Nganjuk Hospital. The population was all postoperative sectio caesarean patients with SAB anesthesia in the Maternity Room Nganjuk Regional Hospital as many as 17 respondents. 2 respondents can't following the study because 1 respondents bleding post partum and 1 respondent except study. Sampling uses accidental sampling. A sample of 15 respondents. The independent variable was warm compress while the dependent variable was recovery of intestinal peristalsis function. Data collection uses observation sheets and stethoscope. Data analysis using Paired Sample T test with $\alpha=0.05$. Results : The mean peristaltic of the respondent's intestine before being given warm compress therapy is $3 \mathrm{x} /$ minute, which means that intestinal peristalsis decreases while the mean after being given a warm compress is $12.93 \mathrm{x} /$ minute, which means normal intestinal peristaltic. Statistical test results of Paired Sample T test obtained $\mathrm{p}$ value $=0,000 \leq \alpha=0,05$ so Ha was accepted. There is an effect of warm compresses on the recovery of intestinal peristalsis function in postoperative sectio caesaria patients with SAB anesthesia in the Maternity Room Nganjuk Hospita. Conclusions : The warm compressing jugs in the abdominal area results in stretching of the abdominal wall. Abdominal wall stretching and vasodilation of blood vessels will stimulate the sympathetic nerves, thus activating the myenteric plexus and stimulating intestinal peristaltic.
\end{abstract}

Keywords: Warm Compress, Intestinal Peristaltic, Postoperative Sectio Caesaria

\section{PENDAHULUAN}

Persalinan Sectio Caesaria merupakan pembedahan untuk melahirkan janin dengan sayatan pada dinding uterus melalui dinding depan perut (Kasdu, 2003). Operasi Sectio Caesaria ada dua macam jenis anastesi yaitu Sub Arachnoid Blok (SAB) dan General Anastesi, akan tetapi jenis anastesi SAB dianggap lebih aman untuk ibu dan janin. Meskipun anastesi SAB ini juga dapat mempengaruhi beberapa hal yaitu dapat mempengaruhi tonus otot pasien yang menyebabkan mual muntah, asfiksia, syok, hipotensi, distensi abdomen. Pada pasca pembedahan selama 24 jam diharapkan fisiologis usus kembali 
normal. Walaupun terdengar bising usus akan tetapi absorbsi belum baik, hal ini bukan berarti peristaltik usus sudah berfungsi dengan efisien (Gorgeous Beaches, 2008). Berdasarkan hasil studi pendahuluan dan pengamatan yang dilakukan oleh peneliti di Kamar Bersalin RSUD Nganjuk pada 19 Agustus 2017 pada 5 pasien post operasi Sectio Caesaria. Selama di ruangan hanya dianjurkan istirahat belum dilakukan terapi non farmakologis untuk meningkatkan peristaltik usus seperti kompres hangat.

WHO telah menetapkan indikator persalinan dengan cara operasi Sectio Caesaria mencapai 5-15\% untuk setiap negara berdasarkan data Riskesdas tahun 2010. Rumah sakit pemerintah rata-rata mencapai $11 \%$ dan di rumah sakit swasta bisa lebih dari 30\% (Judhita, 2009). Di Indonesia secara umum jumlah persalinan Sectio Caesaria adalah sekitar 30-80\% dari total persalinan. Angka kejadian Sectio Caesaria di Indonesia menurut data survey nasional tahun 2007 adalah 927.000 dari 4.039 .000 persalinan yaitu sekitar 23\%. Jumlah persalinan Sectio Caesaria di rumah sakit pemerintah dan swasta memiliki perbedaan yaitu di rumah sakit pemerintah adalah sekitar 20-25\% dari total jumlah persalinan, sedangkan di rumah sakit swasta jumlah lebih besar yaitu sekitar 30-80\%. Di RSUD Nganjuk angka kejadian Sectio Caesaria dari bulan
Juli 2016 s/d Juni 2017 adalah 397 dari 1.768 persalinan yaitu $22,45 \%$ (RSUD Nganjuk, 2017).

Pada pasien sectio caesaria yang menggunakan anastesi SAB maupun GA mempunyai efek penurunan fungsi gastrointestinal sampai dengan 24 jam post Sectio Caesaria dan kembali normal yang akan ditandai dengan adanya flatus. Efek anastesi akan mulai hilang dalam waktu 6 jam, dengan kata lain pengaruh anastesi pada sistem tubuh seperti respiratory, gastrointestinal, kardiovaskular akan hilang (Kehlet, $\mathrm{H}$ 2009). Efek yang ditimbulkan pada gastrointestinal yang dapat menghambat peristaltik usus adalah distensi. Distensi disebabkan oleh peristaltik usus yang melambat akibat anastesi, manipulasi usus atau imobilisasi. Distensi berat pada dinding usus akan mengurangi pengaliran air dan natrium dari lumen usus ke darah. Sekitar 8 liter cairan diekskresi ke dalam saluran cerna setiap hari, sehingga tidak adanya absorsi dapat mengakibatkan penimbunan intralumen dengan cepat (Price, 2005). Efek anestesi ini dapat bertahan selama 6-8 jam setelah pemberian obat anestesi. Anestesi memperlambat motilitas gastrointestinal dan menyebabkan mual sehingga terjadi kelemahan peristaltik usus (Widyaswari DKK, 2015). Seorang pasien yang belum pulih peristaltik ususnya setelah 
pembiusan dapat menderita illeus bila dalam waktu tersebut diberikan asupan nutrisi (Wiyono dan Arifah, 2008).

Tindakan yang dapat dilakukan untuk menurunkan efek buruk dari dampak anastesi adalah dengan pemberian oksigenasi, mempertahankan ventilasi pulmonal, mempertahankan jalan nafas yang efektif, pemberian kompres hangat dan mengatur posisi. Pemberian kompres hangat merupakan salah satu tindakan mandiri keperawatan, dengan memakai prinsip penghantar panas melalui cara konduksi. Rasa hangat yang ditimbulkan oleh kompres hangat pada sistemik dapat mengurangi nyeri, memberi rasa nyaman dan tenang pada klien, memperlancar eksudat, serta merangsang peristaltik usus sehingga dapat segera menurunkan distensi abdomen (Long, 2009). Penggunaan kompres hangat untuk merangsang peristaltic usus dan mengakhiri puasa sebagai tolak ukur peristaltik usus telah pulih dan kembali normal. Dari fenomena dan studi pendahuluan diatas peneliti merasa perlu melakukan penelitian tentang "Pengaruh Pemberian Kompres Hangat Terhadap Pemulihan Fungsi Peristaltik Usus Pada Pasien Post Operasi Sectio Caesaria dengan anastesi SAB di Kamar Bersalin RSUD Nganjuk" guna memperoleh pemahaman lebih jauh tentang pengaruh pemberian kompres pada pasien post operasi Sectio Caesaria.

\section{METODE PENELITIAN}

Desain penelitian adalah pra eksperimen dengan pendekatan one group pretest-posttest design. Penelitian dilaksanakan tanggal 1 - 30 April 2018 di Kamar Bersalin RSUD Nganjuk. Populasi adalah semua pasien post operasi sectio caesaria dengan anestesi SAB di Kamar Bersalin RSUD Nganjuk sebanyak 17 responden. Sampling menggunakan accidental sampling. Sampel sebanyak 15 responden. 2 responden tidak dapat mengikuti penelitian dikarenakan 1 responden mengalami perdarahan setelah melahirkan dan 1 responden menolak ikut penelitian. Variabel independen adalah kompres hangat dengan indikator buli-buli diisi dengan air hangat, suhu air $48-50^{\circ} \mathrm{C}$, diletakkan di daerah abdomen selama 15 menit, dilakukan $3 x$ dalam interval 3 jam selama 15 menit pada jam ke 6, 9, 12 post operasi sectio caesaria, dilakukan di kamar bersalin setelah pasien pindah dari kamar operasi dan air hangat selalu diganti pada setiap pasien dan sebelum dilakukan kompres berikutnya. Sedangkan variabel dependen adalah pemulihan fungsi peristaltik usus dengan indikator frekuensi bising usus diobservasi saat sebelum dilakukan kompres hangat, pada jam ke 6, 9 dan 12 post operasi. Lama observasi 1 menit. Pengumpulan data menggunakan 
lembar observasi dan stetoskop. Analisa

dengan $\alpha=0,05$

data menggunakan Paired Sample T test

\section{HASIL PENELITIAN}

1. Pengaruh Pemberian Kompres Hangat Terhadap Pemulihan Fungsi Peristaltik Usus Pada

Pasien Post Operasi Sectio Caesaria Dengan Anastesi SAB Di Kamar Bersalin RSUD

Nganjuk

Tabel 1 Tabulasi Pengaruh Pemberian Kompres Hangat Terhadap Pemulihan Fungsi Peristaltik Usus Pada Pasien Post Operasi Sectio Caesaria Dengan Anastesi SAB Di Kamar Bersalin RSUD Nganjuk.

\begin{tabular}{|c|c|c|}
\hline \multirow{2}{*}{ No. } & \multicolumn{2}{|c|}{$\begin{array}{c}\begin{array}{c}\text { Peristaltik Usus Sebelum Pemberian } \\
\text { Kompres Hangat }\end{array} \\
\end{array}$} \\
\hline & $\begin{array}{l}\text { Sebelum Pemberian } \\
\text { Kompres Hangat }\end{array}$ & $\begin{array}{c}\begin{array}{c}\text { Setelah Pemberian } \\
\text { Kompres Hangat }\end{array} \\
\end{array}$ \\
\hline 1. & 3 & 13 \\
\hline 2. & 2 & 12 \\
\hline 3. & 3 & 13 \\
\hline 4. & 3 & 13 \\
\hline 5. & 4 & 12 \\
\hline 6. & 2 & 12 \\
\hline 7. & 3 & 14 \\
\hline 8. & 3 & 13 \\
\hline 9. & 2 & 11 \\
\hline 10. & 2 & 12 \\
\hline 11. & 2 & 12 \\
\hline 12. & 4 & 14 \\
\hline 13. & 3 & 14 \\
\hline 14. & 5 & 15 \\
\hline 15. & 4 & 14 \\
\hline & $\begin{array}{c}\text { Mean : } 3, \text { Median }: 3, \\
\text { Standar Deviation }: 0,9258, \\
\text { Minimum }: 2, \\
\text { Maximum }: 5 \\
\end{array}$ & $\begin{array}{c}\text { Mean : 12,93, Median }: 13, \text { Standar Deviation }: 1,099, \\
\text { Minimum }: 11, \\
\text { Maximum }: 15\end{array}$ \\
\hline
\end{tabular}

Berdasarkan tabel 3 terlihat perbedaan rata-rata peristaltik usus sebelum dan sesudah diberikan kompres hangat. Sebelum diberikan kompres hangat rata-rata peristaltik usus adalah $3 \mathrm{x} /$ menit sedangkan setelah diberikan kompres hangat meningkat menjadi 12,93x/menit. Hasil uji statistik dengan mengunakan uji Paired Sample T test didapatkan $p$ value $=0,000 \leq \alpha=$ 0,05 sehingga $H_{a}$ diterima, yang berarti ada pengaruh pemberian kompres 
hangat terhadap pemulihan fungsi peristaltik usus pada pasien post operasi sectio caesaria dengan anastesi $\mathrm{SAB}$ di Kamar Bersalin RSUD Nganjuk

\section{PEMBAHASAN}

1. Fungsi Peristaltik Usus Pada Pasien Post Operasi Sectio Caesaria Dengan Anastesi SAB Sebelum Pemberian Kompres Hangat Di Kamar Bersalin RSUD Nganjuk.

Hasil penelitian pada tabel 1 nilai mean (rata-rata) dari peristaltik usus sebelum diberikan terapi kompres hangat adalah $3 \mathrm{x} /$ menit yang berarti peristaltik usus menurun dengan standar deviasi 0,9258 sedangkan nilai peristaltik usus minimal adalah 2 $\mathrm{x} /$ menit dan maksimal $5 \mathrm{x} /$ menit. Dari 15 responden 4 responden $(66,7 \%)$ berusia 21-30 tahun, 4 responden $(66,7 \%)$ tamat SMA, 4 responden $(66,7 \%)$ merupakan ibu rumah tangga, 3 responden (50\%) merupakan persalinan pertama, 4 responden (66,7\%) merupakan tindakan SC pertama. Hasil uji statistik data demografi sebelum diberikan kompres hangat di dapatkan hasil secara statistik tidak ditemukan hubungan antara data demografi dengan peristaltik usus dibuktikan dengan $p$ value $>\alpha=0,05$.

Pada pasien sectio caesaria yang menggunakan anastesi $\mathrm{SAB}$ maupun GA mempunyai efek penurunan fungsi gastrointestinal sampai dengan 24 jam post Sectio Caesaria dan kembali normal yang akan ditandai dengan adanya flatus. Efek anastesi akan mulai hilang dalam waktu 6 jam, dengan kata lain pengaruh anastesi pada sistem tubuh seperti respiratory, gastrointestinal, kardiovaskular akan hilang (Kehlet, H 2009). Anestesi merupakan bahan yang diberikan agar pasien menjadi tidak sadar (anestesi umum) atau hanya untuk menghilangkan perasaan (anestesi lokal). Pembedahan yang menggunakan anestesi umum yang melibatkan prosedur mayor, dimana membutuhkan manipulasi jaringan yang luas. Efek anestesi ini dapat bertahan selama 6-8 jam setelah pemberian obat anestesi. Anestesi memperlambat motilitas gastrointestinal dan menyebabkan mual sehingga terjadi kelemahan peristaltik usus (Widyaswari DKK, 2015). Seorang pasien yang belum pulih peristaltik ususnya setelah pembiusan dapat menderita illeus bila dalam waktu tersebut diberikan asupan nutrisi (Wiyono dan Arifah, 2008).

Hasil penelitian menunjukkan ratarata pasien mengalami peristaltik usus yang menurun. Hal tersebut terjadi akibat efek dari anastesi SAB yang diterapkan pada pasien. Anastesi tersebut mempengaruhi beberapa fungsi 
tubuh antara lain kardiovaskuler, pernafasan dan pencernaan. Anastesi SAB dapat memblok impuls saraf ke sistem pencernaan efek yang dihasilkan adalah menurunnya peristaltik usus. Diharapkan dengan penurunan peristaltik usus sistem pencernaan akan beristirahat sehingga tidak mengganggu jalannya operasi.

2. Fungsi Peristaltik Usus Pada Pasien Post Operasi Sectio Caesaria Dengan Anastesi SAB Setelah Pemberian Kompres Hangat Di Kamar Bersalin RSUD Nganjuk.

Hasil penelitian pada tabel 2 nilai mean (rata-rata) dari peristaltik usus setelah diberikan terapi kompres hangat adalah 12,93x/menit dibulatkan $13 \mathrm{x} /$ menit yang berarti peristaltik usus normal dengan standar deviasi 1,099 sedangkan nilai peristaltik usus minimal adalah 11 dan maksimal 15. Dari 5 responden 5 responden (100\%) berusia 21-30 tahun, 3 responden (60\%) tamat SMA, 3 responden $(60 \%)$ merupakan ibu rumah tangga, 5 responden (100\%) merupakan persalinan pertama, 5 responden (100\%) merupakan tindakan SC pertama. Hasil uji statistik data demografi setelah diberikan kompres hangat di dapatkan hasil secara statistik tidak ditemukan hubungan antara data demografi dengan peristaltik usus dibuktikan dengan $p$ value $>\alpha=0,05$.
Pemberian kompres hangat merupakan salah satu tindakan mandiri keperawatan, dengan memakai prinsip penghantar panas melalui cara konduksi. Rasa hangat yang ditimbulkan oleh kompres hangat pada sistemik dapat mengurangi nyeri, memberi rasa nyaman dan tenang pada klien, memperlancar eksudat, serta merangsang peristaltik usus sehingga dapat segera menurunkan distensi abdomen (Long, 2009). Pemberian kompres dengan buli buli hangat didasarkan pada efek terapeutik panas, yaitu mengurangi spasme otot, kekakuan dan meningkatkan aliran darah sehingga merangsang peristaltik usus. Untuk meningkatkan peristaltik, kompres hangat diberikan di area abdomen. buli-buli hangat bermanfaat dalam melancarkan sirkulasi darah, mengurangi rasa sakit, memberi rasa hangat, merangsang peristaltik usus dan peregangan tonus otot (Asmadi, 2008). Pemberian buli-buli hangat pada area abdomen akan mengakibatkan vasodilatasi pembuluh darah, dinding usus tersusun dari otot polos, sehingga mengakibatkan terjadinya peregangan pada seluruh usus. Peregangan dinding usus akan merangsang sistem saraf enterik untuk menimbulkan kontraksi dinding usus dan menimbulkan gerakan peristaltik (Kristanto DKK, 2015). 
Hasil penelitian menunjukan adanya peningkatan peristaltik usus setelah dilakukan kompres hangat. Kompres hangat dengan buli-buli dengan suhu $48-50^{\circ} \mathrm{C}$ pada lokasi abdomen akan menghantarkan panas secara terus menerus. Efek yang ditimbulkan adalah merangsang dinding abdomen sehingga merangsang saraf pencercanan untuk kembali aktif. Selain itu kompres hangat tersebut juga dapat memblokade impuls nyeri sehingga efek post operasi berupa nyeri juga dapat tertangani.

3. Pengaruh Pemberian Kompres Hangat Terhadap Pemulihan Fungsi Peristaltik Usus Pada Pasien Post Operasi Sectio Caesaria Dengan Anastesi SAB Di Kamar Bersalin RSUD Nganjuk

Hasil penelitian pada tabel 3 terlihat perbedaan rata-rata peristaltik usus sebelum dan sesudah diberikan kompres hangat. Sebelum diberikan kompres hangat rata-rata peristaltik usus adalah $3 \mathrm{x} /$ menit sedangkan setelah diberikan kompres hangat meningkat menjadi $12,93 \mathrm{x} / \mathrm{menit}$. Hasil uji statistik dengan mengunakan uji Paired Sample $T$ test didapatkan $\quad p$ value $=0,000 \leq$ $\alpha=0,05$ sehingga $\mathrm{H}_{\mathrm{a}}$ diterima, yang berarti ada pengaruh pemberian kompres hangat terhadap pemulihan fungsi peristaltik usus pada pasien post operasi sectio caesaria dengan anastesi
SAB di Kamar Bersalin RSUD

Nganjuk.

Pemberian kompres hangat merupakan salah satu tindakan mandiri keperawatan, dengan memakai prinsip penghantar panas melalui cara konduksi. Rasa hangat yang ditimbulkan oleh kompres hangat pada sistemik dapat mengurangi nyeri, memberi rasa nyaman dan tenang pada klien, memperlancar eksudat, serta merangsang peristaltik usus sehingga dapat segera menurunkan distensi abdomen (Long, 2009). Pemberian kompres dengan buli buli hangat didasarkan pada efek terapeutik panas, yaitu mengurangi spasme otot, kekakuan dan meningkatkan aliran darah sehingga merangsang peristaltik usus. Untuk meningkatkan peristaltik, kompres hangat diberikan di area abdomen. buli-buli hangat bermanfaat dalam melancarkan sirkulasi darah, mengurangi rasa sakit, memberi rasa hangat, merangsang peristaltik usus dan peregangan tonus otot (Asmadi, 2008). Pemberian buli-buli hangat pada area abdomen selain merangsang peristaltik usus, juga mengakibatkan peregangan dinding abdomen. Peregangan dinding abdomen dan vasodilatasi pembuluh darah akan merangsang saraf para simpatis, sehingga mengaktifkan pleksus mienterikus dan merangsang 
terjadinya peristaltik usus (Kristanto DKK, 2015).

Hasil penelitian menunjukan terdapat pengaruh kompres hangat terhadap peningkatan peristaltik usus. Pada saat dilakukan operasi dengan anastesi $\mathrm{SAB}$ akan mempengaruhi dari sistem persarafan salah satunya di gastrointestinal gejala yang ditemui penurunan peristaltik usus. Efek anastesi tersebut dapat bertahan selama 24 jam sehingga dimungkinkan terjadi komplikasi. Untuk mencegah komplikasi tersebut diperlukan tindakan perawatan salah satunya kompres hangat. Kompres hangat pada area abdomen akan membuat aliran darah pada area tersebut menjadi lancar, akan merangsang dinding abodomen dan vasodilatasi usus sehingga muncul gerakan peristaltik usus. Semakin cepat peristaltik kembali dalam kondisi normal semakin cepat pasien akan dapat mengkonsumsi makanan sehingga nurtisi pasien tetap terpenuhi dan komplikasi dapat dihindarkan.

\section{KESIMPULAN}

Rerata dari peristaltik usus responden sebelum diberikan terapi kompres hangat adalah $3 \mathrm{x} /$ menit yang berarti peristaltik usus menurun sedangkan rerata setelah diberikan kompres hangat adalah adalah $12,93 \mathrm{x} /$ menit yang berarti peristaltik usus normal. Hasil uji statistik Paired Sample T test didapatkan $p$ value $=0,000 \leq \alpha=0,05$ sehingga $\mathrm{H}_{\mathrm{a}}$ diterima. Ada pengaruh pemberian kompres hangat terhadap pemulihan fungsi peristaltik usus pada pasien post operasi sectio caesaria dengan anastesi SAB di Kamar Bersalin RSUD Nganjuk.

Saran dalam penelitian ini antara lain tenaga kesehatan dalam hal ini perawat atau bidan di Kamar Bersalin RSUD Nganjuk dapat memberikan kompres hangat sehingga pasien mendapatkan penanganan yang tepat guna mengatasi komplikasi post operasi ataupun dalam hal memulihkan fungsi peristaltik usus. Diharapkan pihak RSUD Nganjuk meningkatkan pelayanan keperawatan maternitas dengan membuat SOP khusus bagi pasien post operasi terutama pasien sectio caesaria dan penanganan peristaltik usus. Diharapkan masyarakat peduli terhadap keluarganya ketika sedang menjalani persalinan terutama persalinan dengan penyulit yang harus dilakukan operasi SC sehingga penganan pasien lebih cepat. Diharapkan setelah operasi sectio caesaria pasien tetap melakukan kontrol dan menjaga kondisi luka sehingga tidak terjadi infeksi.

\section{DAFTAR PUSTAKA}

Asmadi. (2008). Tekhnik Prosedural Keperawatan Konsep dan Aplikasi Kebutuhan Dasar Manusia. Jakarta: Salemba Medika 
Barbara. C. Long, Billie Fransebner. (2009). Buku Ajar Keperawatan Perioperatif Vol. 1. Jakarta: Penerbit Buku Kedokteran EGC

Gorgeous, Beaches. (2008). Buku Ajar Keperawatan Medikal Bedah. Jakarta: EGC

Jitowiyono, Sugeng, Kristianasari, Weni. (2010). Asuhan Keperawatan Post Operasi. Yogyakarta: Nuha Medika

Juditha, (2009). Tips Praktis Bagi Wanita Hamil. Jakarta : Forum Kita.

Kasdu, Dini. (2003). Operasi Caesar Masalah Dan Solusinya. Jakarta : Puspa Sehat

Kehlet, H. (2009). Can preoperative electrical nociceptive stimulation pain after groin herniotomy. Journal of pain
Kristanto, Kristiyawati, Purnomo. (2015). Perbedaan Efektifitas ROM Pasif Dan Pemberian Buli-Buli Hangat Terhadap Pemulihan Peristaltic Usus Postoperasi Anestesi Umum. Jurnal : Poltekkes Kemenkes Semarang

Price, Sylvia Anderson. (2005). Patofisiologi Konsep Klinis dan Prosesproses Penyakit. Jakarta: EGC

Widyaswari DKK, (2015). Pengaruh ROM Aktif Asistif Terhadap Peristaltik Usus Pada Pasien Post Operasi Dengan General Anestesi Di RSUD Ambarawa. Jurnal : Poltekkes Kemenkes Semarang

Wiyono dan Arifah, (2008). Pengaruh Ambulasi Dini Terhadap Pemulihan Peristaltik Usus Pasien Paska Operasi Fraktur Femur Dengan Anestesi Umum Di RSUI Kustati Surakarta. Berita Ilmu Keperawatan ISSN 1979-2697, Vol 1. No 2. 58 Juni 2008, 57-62c 